\section{Characterisation of the thermostable protease AprX in strains of Pseudomonas fluorescens and impact on the shelf-life of dairy products: preliminary results}

Nadia Andrea Andreani, ${ }^{1}$ Lisa Carraro, ${ }^{1}$ Luca Fasolato,' Stefania Balzan,' Rosaria Lucchini, ${ }^{2}$ Enrico Novelli, ${ }^{1}$ Barbara Cardazzo

'Department of Comparative Biomedicine and Food Science, University of Padua, Legnaro (PD); ${ }^{2}$ Institute for Experimental Veterinary Medicine of Venezie, Legnaro (PD), Italy

\section{Abstract}

Bacterial proteases are involved in food spoilage and shelf-life reduction. Among the bacterial proteases, a predominant role in spoilage of dairy products seems to be played by the thermostable metallo-protease AprX, which is produced by various strains of Pseudomonas fluorescens. Differences in AprX enzyme activity among different strains were highlighted, but the most proteolytic strains were not identified. In this study, the presence of the $a p r X$ gene was evaluated in 69 strains isolated from food matrices and 18 reference strains belonging to the $P$. fluorescens group, which had been previously typed by the multi locus sequence typing method. Subsequently, a subset of reference strains was inoculated in ultra-high temperature milk, and the expression of the aprX gene was evaluated at 22 and $6^{\circ} \mathrm{C}$. On the same milk samples, the proteolytic activity was then evaluated through Azocasein and trinitrobenzenesulfonic acid solution assays. Finally, to assess the applicability of the former assay directly on dairy products the proteolityc activity was tested on industrial ricotta samples using the Azocasein assay. These results demonstrate the spread of $a p r X$ gene in most strains tested and the applicability of Azocasein assay to monitor the proteolytic activity in dairy products.

\section{Introduction}

Thermostable protease activity was indicated as one of the main factors responsible of dairy products spoilage, such as gelation of ultra-high temperature (UHT) milk, with consequences on the shelf-life and significant economic losses for the food industry.
Proteases are predominantly active against the casein fraction, which causes gelation of UHT milk and/or the formation of bitter off-flavors. The gelation of UHT milk derives from the formation of complexes between the $\kappa$-casein and $\beta$-lactoglobulin that are denatured as a result of the heat treatment. Gelation is triggered by enzymatic processes of protein degradation (Rauh et al., 2014; Datta and Deeth, 2001). The proteolysis during storage of UHT milk seems to be a consequence of the interaction between the plasminogen-plasmin system (endogenous protease of the milk) with proteases of bacterial origin. Among the bacterial proteases involved in spoilage processes a predominant role seems to be played by the thermostable metallo-protease AprX, which is produced by various strains of the species Pseudomonas fluorescens. The AprX protease, produced and released by bacteria in milk, is resistant to heat and is able to maintain unaltered its activity even after heat treatments that milk may undergo during its processing such as pasteurization, UHT treatment, and cheese-making (Ismail and Nielsen, 2010; Frohbieter et al., 2005). Such enzyme activities could also have a role during cheese ripening for the formation of flavors in seasoned cheeses, and aromatic characteristics of milk cultures of the $P$. fluorescens group are strain-dependent (Morales et al., 2005; Carraro et al., 2011).

To evaluate proteolytic activity, several assays were developed and applied in $P$. aeruginosa (Kessler and Safrin, 2014) and some of them tested for AprX activity on P. fluorescens strains (Dufour et al., 2008; Marchand et al., 2009a). The AprX protein and its encoding gene have been studied extensively (Liu et al., 2007; Maunsell et al., 2006; Nicodeme et al., 2005; Woods et al., 2001; Liao and McCallus, 1998). Differences in AprX enzyme activities were highlighted, but the identification of the most proteolytic strains was not completely elucidated (Dufour et al., 2008; Marchand et al., 2009a, 2009b). This is due partially to the unreliability of methods currently used for the identification of $P$. fluorescens strains. Recently, $P$. fluorescens was recognized as a species group (Mulet et al., 2010) and a molecular typing approach was developed and applied on several $P$. fluorescens reference and field strains (Andreani et al., 2014). The determination of the genetic diversity among species and strains belonging to the $P$. fluorescens group provides an accurate method for strain identification.

In the present study the presence of the $a p r X$ gene was evaluated in 69 strains isolated from food matrices and 18 reference strains belonging to the $P$. fluorescens group. All strains were previously typed by multi locus sequence typing (MLST) method and allocated in a subgroup as genetically related to a specific reference type strain.
Correspondence: Barbara Cardazzo,

Department of Comparative Biomedicine and Food Science, University of Padua, viale dell'Università 16, 35020 Legnaro (PD), Italy. Tel: +39.049 .8272965 - Fax +39.049 .8272973 .

E-mail: barbara.cardazzo@unipd.it

Key words: Pseudomonas fluorescens; Spoilage; Dairy products; AprX.

Received for publication: 19 July 2016

Revision received: 16 November 2016.

Accepted for publication: 19 November 2016.

This work is licensed under a Creative Commons Attribution-NonCommercial 4.0 International License (CC BY-NC 4.0).

(c)Copyright N.A. Andreani et al., 2016

Licensee PAGEPress, Italy

Italian Journal of Food Safety 2016; 5:6175

doi:10.4081/ijfs.2016.6175

In a selected group of reference strains, the activity and gene expression of AprX were tested in milk. Finally, the applicability of Azocasein assay directly on dairy products was evaluated on industrial ricotta samples. The results demonstrated the spread of $a p r X$ gene in most of the strains tested and the applicability of trinitrobenzenesulfonic acid solution (TNBS) and Azocasein tests to monitor the proteolytic activity in dairy products.

\section{Materials and Methods}

\section{Bacterial strains}

P. fluorescens group strains are listed in Table 1. For each strain, the sequence type (ST) and the subgroup obtained by MLST analysis (Andreani et al., 2014) are reported. Strains were conserved at $-80^{\circ} \mathrm{C}$ in Tryptic Soy Broth [TSB; Oxoid, Basingstoke, UK; with 50\% v/v glycerol (Sigma-Aldrich, Saint Louis, MO, USA)].

\section{DNA and RNA extraction}

For DNA extraction, a single colony from a fresh culture on CFC Pseudomonas Agar Base (CFC PAB; Oxoid) was re-suspended in $100 \mu \mathrm{L}$ of nuclease-free water, vortexed at high speed for 5 seconds and incubated at $95^{\circ} \mathrm{C}$ for 10 minutes. The tube was vortexed again and centrifuged for 2 minutes at 14,000 rpm. The supernatant was transferred to a fresh tube and stored at $-20^{\circ} \mathrm{C}$ (Martino et al., 2011).

For RNA extraction, a single pure colony of each strain was inoculated in triplicate (giving 3 biological replicates for each strain) in $3 \mathrm{~mL}$ MBM Broth [0.7\% $\mathrm{K}_{2} \mathrm{HPO}_{4}, 0.3 \% \mathrm{KH}_{2} \mathrm{PO}_{4}, 0.05 \%$ trisodium citrate, $\quad 0.01 \% \quad \mathrm{MgSO}_{4}, \quad 0.1 \%$ $\left(\mathrm{NH}_{4}\right)_{2} \mathrm{SO}_{4}, 0.2 \%$ glucose] and kept at $22^{\circ} \mathrm{C}$ for 
Table 1. Species, subgroups, food origin, sequence type, presence of $A p r X$ gene and proteolytic activity in plate of Pseudomonas fluorescens strains.

\begin{tabular}{|c|c|c|c|c|c|c|c|c|}
\hline Strain & Species & Subgroup & Source & ST & AprX gene & & litic a & tivity \\
\hline & & & & & & $6^{\circ} \mathrm{C}$ & $22^{\circ} \mathrm{C}$ & $31^{\circ} \mathrm{C}$ \\
\hline DSM 17152T & Pseudomonas gessardii & P. fluorescens subgroup & Mineral water & 7 & + & + & ++ & - \\
\hline DSM 15294T & Pseudomonas brenneri & P. fluorescens subgroup & Natural mineral water & 8 & + & + & ++ & - \\
\hline DSM 17967T & Pseudomonas mandelii & P. mandelii subgroup & Mineral water & 9 & + & + & + & - \\
\hline DSM 17150T & Pseudomonas jessenii & P. jessenii subgroup & Mineral water & 10 & + & - & + & - \\
\hline DSM 16610T & Pseudomonas koreensis & P. koreensis subgroup & Agricultural soil & 11 & + & +++ & + & ++ \\
\hline DSM 17489T & Pseudomonas orientalis & P. fluorescens subgroup & Spring water & 12 & + & +++ & ++ & - \\
\hline DSM 18928T & Pseudomonas synxantha & P. fluorescens subgroup & Cream & 13 & + & ++ & + & - \\
\hline DSM 18862T & Pseudomonas azotoformans & P. fluorescens subgroup & Paddies & 14 & + & +++ & +++ & - \\
\hline DSM 6252T & Pseudomonas lundensis & P. fragi subgroup & Prepacked beef & 15 & + & - & - & - \\
\hline DSM 14020T & Pseudomonas rhodesiae & P. fluorescens subgroup & Natural mineral water & 16 & + & ++ & +++ & - \\
\hline DSM 11331T & Pseudomonas veronii & P. fluorescens subgroup & Mineral water & 17 & + & ++ & ++ & - \\
\hline DSM 17149T & Pseudomonas libanensis & P. fluorescens subgroup & Spring water & 18 & + & +++ & ++ & - \\
\hline DSM50415 & Pseudomonas fluorescens & P. fluorescens subgroup & Soil & 19 & + & ++ & ++ & + \\
\hline CECT124T & Pseudomonas corrugata & P. corrugata subgroup & Tomato: pith necrosis & 20 & + & - & ++ & ++ \\
\hline СЕСТ229T & Pseudomonas marginalis & P. fluorescens subgroup & Cichorium intybus (endive) & 21 & + & - & +++ & - \\
\hline СЕСТ378T & Pseudomonas fluorescens & P. fluorescens subgroup & Pre-filter tanks, town water works & 22 & + & ++ & ++ & - \\
\hline CECT446T & Pseudomonas fragi & P. fragi subgroup & Unknown & 23 & + & +++ & +++ & - \\
\hline СЕСТ4470T & Pseudomonas chlororaphis & P. clororaphis group & Plate contaminant & 24 & + & ++ & ++ & ++ \\
\hline ps_1 & & P. fluorescens subgroup & Mozzarella cheese & 25 & + & + & ++ & - \\
\hline ps_2 & & P. fluorescens subgroup & Blue mozzarella cheese & 26 & + & ++ & ++ & - \\
\hline ps_3 & & P. fragi subgroup & Mozzarella cheese & 27 & + & - & - & - \\
\hline ps_4 & & P. fluorescens subgroup & Mozzarella cheese & 28 & + & - & +++ & - \\
\hline ps_5 & & P. fluorescens subgroup & Mozzarella cheese & 29 & + & - & ++ & - \\
\hline ps_6 & & P. fluorescens subgroup & Blue mozzarella cheese & 30 & + & ++ & ++ & - \\
\hline ps_7 & & P. koreensis subgroup & Mozzarella cheese & 31 & + & +++ & +++ & - \\
\hline ps_8 & & P. fluorescens subgroup & Mozzarella cheese & 32 & + & +++ & +++ & - \\
\hline ps_9 & & P. fluorescens subgroup & Mozzarella cheese & 33 & - & ++ & ++ & - \\
\hline ps_10 & & P. fluorescens subgroup & Mozzarella cheese & 34 & + & ++ & ++ & - \\
\hline ps_11 & & P. fluorescens subgroup & Mixed salad & 35 & + & + & ++ & - \\
\hline ps_12 & & P. fragi subgroup & Butter & 36 & + & - & - & - \\
\hline ps_13 & & P. fluorescens subgroup & Blue mozzarella cheese & 37 & + & ++ & ++ & - \\
\hline ps_14 & & P. koreensis subgroup & Pork & 38 & + & - & + & + \\
\hline ps_15 & & P. fluorescens subgroup & Salmo trutta marmoratus (trout) & 39 & + & ++ & ++ & - \\
\hline ps_16 & & P. fluorescens subgroup & Salmo trutta fario (trout) & 40 & + & +++ & +++ & ++ \\
\hline ps_17 & & P. fragi subgroup & Ricotta & 41 & + & ++ & + & - \\
\hline ps_18 & & P. fluorescens subgroup & UHT milk & 42 & + & ++ & ++ & ++ \\
\hline ps_19 & & P. fragi subgroup & UHT milk & 43 & - & - & + & ++ \\
\hline ps_20 & & P. fluorescens subgroup & UHT milk & 44 & + & +++ & ++ & + \\
\hline ps_21 & & P. koreensis subgroup & Mozzarella cheese & 45 & + & + & + & - \\
\hline ps_22 & & P. fluorescens subgroup & Blue mozzarella cheese & 46 & + & + & ++ & - \\
\hline ps_23 & & P. koreensis subgroup & Mozzarella cheese & 47 & + & - & ++ & - \\
\hline ps_24 & & P. fluorescens subgroup & Cheese & 48 & + & - & ++ & - \\
\hline ps_25 & & P. fluorescens subgroup & UHT milk & 49 & + & - & + & - \\
\hline ps_26 & & P. koreensis subgroup & Human & 50 & + & ++ & ++ & ++ \\
\hline ps_27 & & P. fluorescens subgroup & Mixed salad & 51 & + & ++ & ++ & - \\
\hline ps_28 & & P. koreensis subgroup & Mixed salad & 52 & + & ++ & +++ & +++ \\
\hline ps_29 & & P. fluorescens subgroup & Mixed salad & 53 & + & +++ & +++ & - \\
\hline ps_30 & & P. fluorescens subgroup & Mixed salad & 54 & + & + & +++ & - \\
\hline ps_31 & & P. fluorescens subgroup & Mixed salad & 55 & + & ++ & +++ & - \\
\hline ps_32 & & P. clororaphis group & Mixed salad & 56 & + & - & - & - \\
\hline ps_33 & & P. fluorescens subgroup & Mixed salad & 57 & + & ++ & ++ & - \\
\hline ps_34 & & P. fluorescens subgroup & Mixed salad & 58 & + & +++ & +++ & - \\
\hline
\end{tabular}


$24 \mathrm{~h}$ to reach $10^{8} \mathrm{CFU} / \mathrm{mL}$. Then, cultures were diluted five times in $3 \mathrm{~mL}$ of milk. After $24 \mathrm{~h}$ of incubation at $22^{\circ} \mathrm{C}$ or five days at $5^{\circ} \mathrm{C}, 1 \mathrm{~mL}$ of culture was then extracted using the RNAeasy Mini Kit (Qiagen, Hilden, Germany) following the manufacturer's protocol. DNase treatment was performed using the Qiagen RNase-Free DNase Set (Qiagen). RNA was eluted in $30 \mu \mathrm{L}$ of RNAse-free $\mathrm{H}_{2} \mathrm{O}$. Purified DNA and RNA were quantified using a NanoDrop ND-1000 spectrophotometer (NanoDrop Technologies, Wilmington, DE, USA). One microgram of total RNA for each sample was reverse transcribed to cDNA using SuperScript ${ }^{\circledR}$ II Reverse Transcriptase (Invitrogen, Carlsbad, CA, USA). To evaluate DNA contamination in RNA samples treated with DNAse, no-RT (reverse-transcriptase) samples were also checked in PCR amplification.

\section{Polymerase chain reaction amplifi- cation}

Primers for $a p r X$ gene amplification were designed using PriFi software (http://cgiwww.daimi.au.dk/cgi-chili/PriFi; Fredslund et al., 2005) using as template the alignment of aprX sequences from complete genomes of $P$. fluorescens group already available in Genbank (http://www.ncbi.nlm.nih.gov/genome). The sequence of primers was Pse_AprXF1 CAGACCCTGACCCACGARATCGG and Pse_AprXR1 TGAGGTTGATCTTCTGGTTCTGGG. The $r p o D$ housekeeping gene was used as positive control for DNA and RNA extraction using primers reported in Andreani et al. (2014).

PCR amplifications were performed in an Applied Biosystems 2720 Thermal Cycler
(Thermo Fisher Scientific, Waltham, MA, USA) in a final volume of $20 \mu \mathrm{L}$ of amplification mix containing 1U of GoTaq polymerase (Promega, Madison, WI, USA), 1X GoTaq Buffer, $1.5 \mathrm{mM}$ $\mathrm{MgCl}_{2}, 0.2 \mathrm{mM}$ each deoxynucleotide triphosphate (dNTP), $250 \mathrm{mM}$ each primer and $5 \mathrm{ng}$ of genomic DNA as template. The reaction mixture was subjected to the following thermal cycle: an initial step at $94^{\circ} \mathrm{C}$ for 2 min to activate the polymerase and 35 cycles each of denaturation at $94^{\circ} \mathrm{C}$ for 20 seconds, annealing of the primers at $60^{\circ} \mathrm{C}$ for 30 seconds and extension at $72^{\circ} \mathrm{C}$ for 1 minute and a final step of extension at $72^{\circ} \mathrm{C}$ for $7 \mathrm{~min}$. Amplified products were analysed by electrophoresis on $1.8 \%$ agarose-Tris-acetate-EDTA (TAE) gels, stained with SYBR ${ }^{\circledR}$ Safe DNA Gel Stain (Invitrogen) and visualized on a UV transilluminator (Gel Doc XR ${ }^{\mathrm{TM}}$; Biorad, Hercules, CA, USA).

Table 1. Continued from previous page.

\begin{tabular}{|c|c|c|c|c|c|c|c|}
\hline Strain & Species & Source & ST & AprX gene & $\mathrm{Pl}_{1}$ & litic a & \\
\hline & & & & & $6^{\circ} \mathrm{C}$ & $22^{\circ} \mathrm{C}$ & $31^{\circ} \mathrm{C}$ \\
\hline ps_35 & P. fluorescens subgroup & Mixed salad & 59 & + & +++ & ++ & - \\
\hline ps_36 & P. fluorescens subgroup & Mixed salad & 60 & + & +++ & ++ & - \\
\hline ps_37 & P. clororaphis subgroup & Mixed salad & 61 & + & + & ++ & +++ \\
\hline ps_38 & P. clororaphis subgroup & Mixed salad & 62 & + & + & ++ & +++ \\
\hline ps_39 & P. fluorescens subgroup & Mixed salad & 63 & + & ++ & ++ & + \\
\hline ps_40 & P. fluorescens subgroup & Ricotta & 64 & + & +++ & ++ & - \\
\hline ps_48 & P. fragi subgroup & Pork & 72 & + & ++ & +++ & + \\
\hline ps_50 & P. fragi subgroup & Pork & 74 & + & ++ & +++ & +++ \\
\hline ps_51 & P. clororaphis group & Pork & 75 & + & ++ & +++ & +++ \\
\hline ps_54 & P. fragi subgroup & Pork & 78 & + & ++ & ++ & + \\
\hline ps_55 & P. koreensis subgroup & Pork & 79 & + & - & ++ & +++ \\
\hline ps_56 & P. koreensis subgroup & Sashimi & 80 & + & + & ++ & +++ \\
\hline ps_57 & P. fluorescens subgroup & Sashimi & 81 & + & ++ & +++ & ++ \\
\hline ps_58 & P. corrugata subgroup & Sashimi & 82 & + & - & ++ & ++ \\
\hline ps_59 & P. fluorescens subgroup & Sashimi & 83 & + & +++ & +++ & ++ \\
\hline ps_60 & nd & Sashimi & nd & + & +++ & +++ & +++ \\
\hline ps_61 & P. fluorescens subgroup & Sashimi & 84 & + & + & +++ & ++ \\
\hline ps_62 & nd & Sashimi & nd & + & + & +++ & +++ \\
\hline ps_63 & 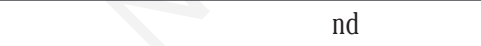 & Sashimi & nd & + & ++ & +++ & ++ \\
\hline ps_64 & P. fluorescens subgroup & Sashimi & 85 & + & - & +++ & + \\
\hline ps_65 & P. koreensis subgroup & Rocket & 86 & + & ++ & +++ & +++ \\
\hline ps_66 & P. koreensis subgroup & Rocket & 87 & + & ++ & +++ & +++ \\
\hline ps_67 & P. koreensis subgroup & Valerian & 88 & + & ++ & +++ & +++ \\
\hline ps_68 & P. corrugata subgroup & Valerian & 89 & + & - & +++ & +++ \\
\hline ps_69 & P. mandelii subgroup & Dairy-product & 90 & + & - & + & + \\
\hline ps_70 & P. fragi subgroup & Dairy-product & 91 & + & + & ++ & - \\
\hline ps_71 & P. fragi subgroup & UHT milk & 92 & - & + & + & + \\
\hline ps_72 & P. fragi subgroup & Dairy-product & 93 & + & - & ++ & + \\
\hline ps_73 & P. fluorescens subgroup & Dairy-product & 94 & - & - & + & - \\
\hline ps_74 & P. fragi subgroup & Dairy-product & 95 & + & ++ & + & + \\
\hline ps_75 & P. fluorescens subgroup & Blue mozzarella cheese & 29 & + & - & ++ & - \\
\hline ps_76 & P. fluorescens subgroup & Mozzarella cheese & 26 & + & ++ & ++ & - \\
\hline ps_77 & P. fluorescens subgroup & Meat & 96 & + & - & ++ & - \\
\hline ps_78 & P. fluorescens subgroup & Mozzarella cheese & 97 & + & - & + & - \\
\hline Ps_79 & P. fluorescens subgroup & Meat & 98 & + & - & - & - \\
\hline
\end{tabular}

ST, sequence type; UHT, ultra-high temperature; nd, not determined. 


\section{Proteolytic activity in plate}

The reference and field strains were tested for their proteolytic activity by agar diffusion assays at $6^{\circ} \mathrm{C}$ for 10 days, at 22 and $31^{\circ} \mathrm{C}$ for 7 days. All the strains were revitalized through a 72-hours-preinoculum in TSB at $22^{\circ} \mathrm{C}$. A dilution of $10^{5} \mathrm{CFU} / \mathrm{mL}$ was applied for the subsequent tests. The extracellular protease activity evaluation was conducted on Nutrient Agar (NA; Biokar diagnostics, Paris, France) with $2 \%$ UHT milk observing a clear zone around the colonies. The presence of a clear zone around the colonies after incubation was indicative for proteolysis.

\section{Quantification of extracellular pro- teolytic activity (Azocasein assay)}

Proteolytic activity of bacterial strains was quantified using Azocasein (Sigma-Aldrich) as substrate. One hundred $\mu \mathrm{L}$ of a $3 \%(\mathrm{w} / \mathrm{v})$ Azocasein stock solution were added to $100 \mu \mathrm{L}$ of cell free supernatant fluid and $300 \mu \mathrm{L}$ of 50 $\mathrm{mM} \mathrm{Na}_{2} \mathrm{HPO}_{4} \mathrm{pH}$ 7.5. The negative control was set up with $100 \mu \mathrm{L}$ of not inoculated milk. The mixture was incubated at $37^{\circ} \mathrm{C}$ for $1 \mathrm{~h}$ and the reaction was stopped by adding $500 \mu \mathrm{L}$ of $20 \%$ (w/v) trichloroacetic acid (TCA). The sample was centrifuged at $12,000 \mathrm{~g}$ for $10 \mathrm{~min}$ and absorbance of the supernatant was measured at $366 \mathrm{~nm}$ using Multiskan GO UV/Nis spectrophotometer (Thermo Fisher Scientific). Absorbance of the blank (500 $\mu \mathrm{L}$ not incubated sample plus $500 \mu \mathrm{L}$ of TCA $20 \%$ ), and of the negative control were subtracted from sample absorbance. The results are reported as $\mathrm{OD}_{366}$.

\section{Quantification of proteolysis (trinitrobenzenesulfonic acid solution test)}

The experimental set-up made it possible to calculate the net proteolytic activity produced during 2 weeks of storage at $37^{\circ} \mathrm{C}$ after a heat treatment simulating UHT process and storage (as described in Marchand et al., 2008, 2009a). Hydrolysis of proteins was measured by the determination of the release of a-amino groups by the trinitrobenzenesulfonic acid (TNBS) method. The free amino groups react with the TNBS reagent (Sigma-Aldrich) at $\mathrm{pH}$ 9.2 in the dark. A yellow-orange colour develops and its intensity is determined by absorption measurements at $420 \mathrm{~nm}$. The degree of proteolysis is calculated from the increase in absorption after 2 weeks of storage at $37^{\circ} \mathrm{C}$ and expressed as mmol of glycine equivalents $\mathrm{mL}$ 1 milk, using glycine $(2.5,2.25,2,1.75,1.5$, $1.25,1,0.75,0.5,0.25$ e 0 mM; Sigma-Aldrich) to create a standard curve. The experiment was repeated twice, first in macro method (experiment A using a 7800 UV/VIS spectrophotometer; JASCO, Easton, MD, USA) and second time in micro method (experiment B using a Multiskan GO UV/Nis spectrophotometer (Thermo Fisher Scientific).

\section{Proteolytic activity in industrial ricotta samples}

Of ricotta samples, $10 \mathrm{~g}$ were inoculated with $1 \mathrm{~mL}$ of a $10^{8} \mathrm{cell} / \mathrm{mL}$ of a fresh culture of $P$. fluorescens group strains growth in TSB in sterile $50 \mathrm{~mL}$ tubes and were maintained at refrigeration temperature for seven days. The Azocasein assay was carried out in order to evaluate the proteolytic activity of the inoculated ricotta in comparison to three industrial ricotta samples, belonging to the same lot, collected and analyzed $24 \mathrm{~h}$ from production. One gr of ricotta was sampled in duplicate from each of the four inoculated samples and the three fresh ricotta samples and diluted in $5 \mathrm{~mL}$ of Phosphate-buffered saline (PBS). After mixing, $2 \mathrm{~mL}$ were centrifuged at $12,000 \mathrm{rpm}$ for 5 minutes, then $100 \mu \mathrm{L}$ of the supernatant was used for the Azocasein assay as previously described.

\section{Results}

\section{Distribution of the aprX gene in}

\section{Pseudomonas fluorescens group}

The distribution of the $a p r X$ gene was evaluated on 18 reference and 69 field strains and the result is reported in Table 1. Only for four strains (4.6\%) the PCR amplification of $a p r X$ gene, repeated twice, gave a negative result. All these four strains resulted positive to the amplification of the $r p o D$ gene. The four strains belonged to the $P$. fluorescens subgroup (ps_9 and ps_73) or to the $P$. fragi subgroup (ps_19 and ps_71).

\section{Proteolytic activity of \\ Pseudomonas fluorescens strains in plate}

Proteolytic activity was observed at least at one temperature condition in 17 reference strains and 65 fields strains (for a total of $94.2 \%$ ), indicating that proteolysis is a common spoilage mechanism for $P$. fluorescens group strains. The non-proteolytic strains are P. lundensis DSM6252T, ps_3, ps_12, ps_32, ps_79. The complete data are reported in Table 1.

\section{Proteolytic activity and aprX gene expression in milk samples inocu- lated with Pseudomonas fluo- rescens}

The experiment was set up to simulate the conditions during UHT milk production (as described in Marchand et al., 2008, 2009a) and a schematic representation of the analyses is reported in Figure 1. Briefly, $100 \mu \mathrm{L}\left(10^{7}\right.$ cells $)$ of a fresh culture of each strain was inoculated in $10 \mathrm{~mL}$ of UHT milk and grown for 24 hours. An aliquot of $100 \mu \mathrm{L}$ of the culture was then inoculated in $10 \mathrm{~mL}$ of UHT milk and grown for 24 hours. Double growth in milk until exponential phase was done to adapt bacterial strains to milk. The culture was then diluted to $10^{3} \mathrm{cfu} / \mathrm{mL}$ in UHT milk and incubated at $6^{\circ} \mathrm{C}$ for five days. At the end of the incubation, the Azocasein test was performed as described in Materials and Methods to measure the global proteolytic activity (thermoresistent and non-

Table 2. Proteolityc activity and $A p r X$ gene expression in Pseudomonas fluorescens group references strains.

\begin{tabular}{|c|c|c|c|c|c|c|c|c|c|c|c|}
\hline Type strains & Subgroups & Pro & $\begin{array}{l}\text { olitic : } \\
\text { plate }\end{array}$ & ivity & $\begin{array}{l}\text { AprX } \\
\text { expr }\end{array}$ & $\operatorname{ion}^{\circ}$ & $\begin{array}{r}\text { Aro } \\
0\end{array}$ & sein & TNBS" $\mathrm{m}$ & V glicine & $\begin{array}{l}\text { Avocasein }^{\S} \\
\text { Ricotta } \text { OD }_{36}\end{array}$ \\
\hline & & $6^{\circ} \mathrm{C}$ & $22^{\circ} \mathrm{C}$ & $31^{\circ} \mathrm{C}$ & $22^{\circ} \mathrm{C}$ & $6^{\circ} \mathrm{C}$ & Pre-HT & Post-HT & Experiment A & Experiment B & \\
\hline DSM 17489T & P. orientalis & +++ & ++ & - & +++ & +-+ & 0.28 & 0.22 & 3.69 & 11.85 & 1.02 \\
\hline DSM 6252T & P. lundensis & - & - & - & --- & --- & 0.02 & 0.01 & 1.92 & 6.72 & nd \\
\hline DSM 14020T & P. rhodesiae & ++ & +++ & - & +++ & -- & 0.07 & 0,04 & 1.71 & 24.09 & 0.34 \\
\hline DSM 17149T & P. libanensis & +++ & ++ & - & +++ & -- & 0.37 & 0.17 & - & - & 1.38 \\
\hline CECT378T & P. fluorescens & ++ & ++ & - & ++- & -- & 0.1 & 0.03 & 3.15 & 7.24 & 1.01 \\
\hline CECT446T & P. fragi & +++ & +++ & - & +++ & -- & 0.28 & 0.18 & - & - & nd \\
\hline CECT229T & P. marginalis & - & +++ & - & --- & --- & 0.01 & 0.02 & - & - & nd \\
\hline
\end{tabular}

TNBS, trinitrobenzenesulfonic acid solution; HT, high-temperature. ${ }^{*}+,++$ or +++ depending on the size of the clear zone around the colonies; ${ }^{\circ}+$ or - is positive or negative result in the amplification of each triplicate; "experiment A was performed in macromethods, Experiment B in micromethods; ${ }^{8}$ reported the average between the OD of the duplicates. nd, not determined. 
thermoresistent proteases). The culture was then heat-treated $(10 \mathrm{~mL}$ for 8 minutes and 45 seconds at $95^{\circ} \mathrm{C}$ to simulate UHT treatment) and a second Azocasein test was performed to measure the thermoresistent protease activity. The culture was then incubated for two weeks at $37^{\circ} \mathrm{C}$. After incubation, the TNBS test was performed as described in Materials and Methods section.

This preliminary experiment was performed with six reference strains, including a negative control (not inoculated milk) and the results are summarized in Table 2 . The gene expression study demonstrated that, in the condition tested, the $a p r X$ gene is not expressed in $P$. lundensis and $P$. marginalis. The Azocasein assay gave $0_{366}$ values ranging from 0.01 to 0.37 . The TNBS assays gave values in $\mathrm{mM}$ Glycin from 0 (negative results for three strains) to 24.09 in micro method and from 0 to 3.69 in macro method. Proteolytic activity data is only partially in agreement with expression data.

\section{Proteolytic activity in industrial ricotta samples}

The results of proteolytic activity measured on ricotta samples are reported in Table 2 and Figure 2 . The data evidenced variable activity in the freshly produced ricotta samples despite the three samples belonged to the same lot of production.

\section{Discussion}

The analysis of $87 P$. fluorescens strains for the presence of the $a p r X$ gene demonstrated that the gene is widespread in this bacterial group. The aprX negative strains are not strongly genetically related (Andreani et al., 2014) suggesting that the lack of $a p r X$ amplification, could be due to loss of the gene or mis- matches in primer sites that occurred independently in each strain. However, the $a p r X$ gene expression study demonstrated strong variability across strains, which might explain the large variability in proteolytic activity reported in previous studies (Dufour et al., 2008; Marchand et al., 2009a, 2009b).

To evaluate the spoilage activity of AprX in dairy products, milk and ricotta cheese were used as template to inoculate strains positive to $a p r X$ gene. The experimental protocol for milk, reported in Figure 1, was designed to simulate UHT milk productive process, with milk samples incubated first at refrigeration temperature, and after heat treatment, incubated at $37^{\circ} \mathrm{C}$. Similar experimental design to simulate UHT milk production was proposed and applied in previous studies (Marchand et al., 2008, 2009a).

The proteolytic activity was measured with two different assays, the first, the Azocasein assay, measures directly the activity with a colorimetric reaction, the second, the TNBS assay, measures free amino acids (aminogroups), as products of the proteolysis. The two different assays are both easy and fast to be carried out, inexpensive and require a common spectrophotometer. In the present study, these assays were applied to compare their sensibility on dairy products inoculated with a bacterial culture. However, the results of the two assays are only partially comparable. The Azocasein assay results are in good agreement with aprX expression data, if considering value less to $0.05 \mathrm{OD}_{366}$ as negative. On the contrary, TNBS assay results are discordant with $a p r X$ expression and Azocasein assay data for $P$. lundensis and $P$. libanensis. On the basis of these results the Azocasein assay might be more reliable as a direct measure of the enzyme activity, however some concerns remain. First, the Azocasein assay had not a standard curve to be used to compare the results. Secondly, protease activity immediately after the heat treatment might be slower as a consequence of the treatment itself and this effect might be different in the different strains. This effect could be due to differences in protein structure despite the nucleotidic sequence was reported to be very conserved among $P$. fluorescens strains (Marchand et al., 2009b) or to different resistance of strains to heat treatment. The gelation of UHT milk, if occurs, usually takes place after weeks from production. This long time might depend on the time required by proteases to reactivate after heat treatment or to some chemical modification that might occur in milk and activate proteases.

Anyway, this preliminary study strongly confirms strain variability in protease activity. $P$. lundensis and $P$. frag $i$ were indicated as the species mostly involved in spoilage of milk (Marchand et al., 2009a). For these two strains, contrasting results were obtained in the present study. Regarding $P$. lundensis type strain, the $a p r X$ expression was negative in milk as it was proteolytic activity in plate and at Azocasein assay, even if the TNBS assay yielded a positive result. On the contrary, $P$. fragi type strain expressed $a p r X$ and was positive for proteolytic assay both in plate and with Azocasein assay, but was negative with TNBS assay. Thanks to MLST molecular typing, the $P$. fluorescens group fields strains were accurately identified and the application of the experiment in milk using fields strains belonging to $P$. fragi subgroup (that include $P$. lundensis) is interesting to confirm if the spoilage phenotype is related to this taxonomic group.

Finally, with the aim to test the applicability of these assays to analyze dairy products, in which spoilage activity might be due to thermoresistent proteases, industrial ricotta was chosen as a study case. In fact, industrial ricot$t a$ is produced at high temperature $\left(90^{\circ} \mathrm{C}\right)$ and successively pasteurized $\left(80^{\circ} \mathrm{C}\right)$ starting from milk whey that usually presents high bacterial loads (among these bacteria, Pseudomonas is

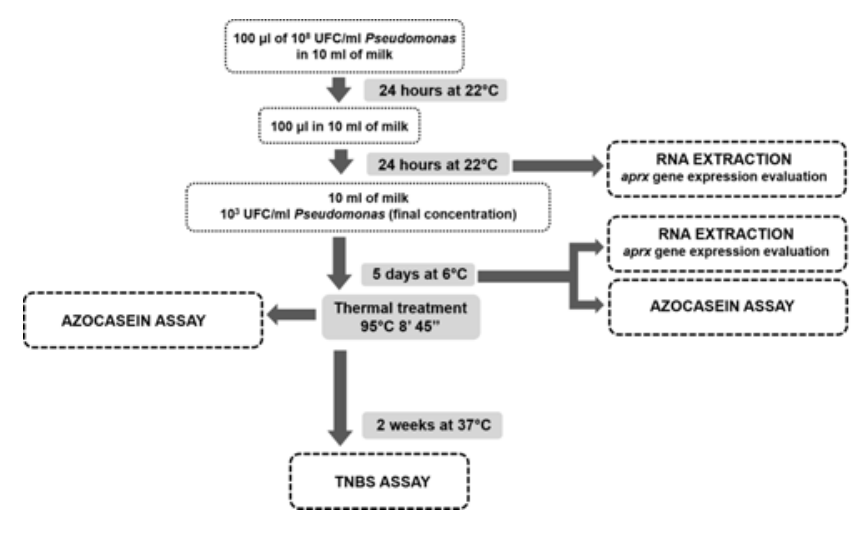

Figure 1. Schematic description of the experiment set-up simulating the conditions of ultra-high temperature milk production.

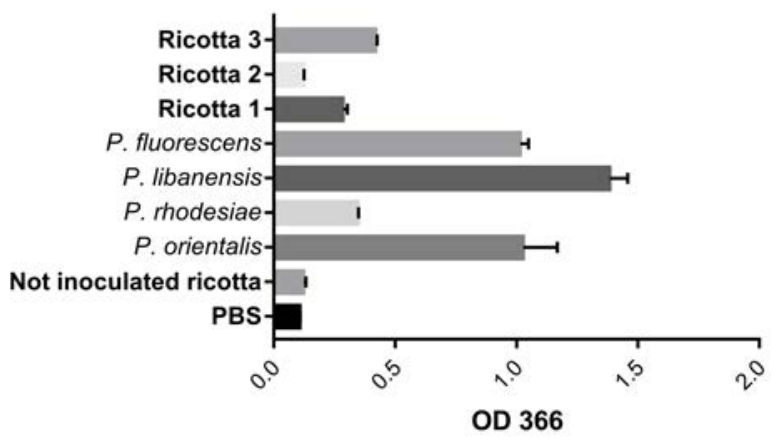

Figure 2. Proteolytic activity in ricotta samples. 
often present). Industrial ricotta often shows premature spoilage that reduces product shelflife. The application of Azocasein assay on freshly produced industrial ricotta samples showed protease activity that might be one of the responsible factors for premature spoilage. This result highlights the importance of good quality raw material to extend shelf-life also for heat-treated products.

\section{Conclusions}

These preliminary data highlight the interest, but also the complexity of studying the proteolytic activity of the $a p r X$ gene in $P$. fluorescens. The availability of MLST-typed strains might help to identify the major $a p r X$ producing strains and evaluate if such spoilage activity is a phenotypic trait linked to specific lineages in the $P$. fluorescens group. Azocasein and TNBS assay should be improved, but might be suitable (in particular the Azocasein assay) to evaluate proteolytic activity in dairy products such as industrial ricotta or UHT milk to assess in advance the spoilage potential during shelf-life.

\section{References}

Andreani NA, Martino ME, Fasolato L, Carraro L, Montemurro F, Mioni R, Bordin P, Cardazzo B, 2014. Tracking the blue: a MLST approach to characterise the Pseudomonas fluorescens group. Food Microbiol 39:116-26.

Carraro L, Maifreni M, Bartolomeoli I, Martino ME, Novelli E, Frigo F, Marino M, Cardazzo B, 2011. Comparison of culture-dependent and culture-independent methods for bacterial community monitoring during Montasio cheese manufacturing. Res Microbiol 162:231-9.

Datta N, Deeth HC, 2001. Age gelation of UHT milk: a review. Trans IChemE 79:197-210.
Dufour D, Nicodème $M$, Perrin $C$, Driou $A$, Brusseaux E, Humbert G, Gaillard JL, Dary A, 2008. Molecular typing of industrial strains of Pseudomonas spp. isolated from milk and genetical and biochemical characterization of an extracellular protease produced by one of them. Int $\mathrm{J}$ Food Microbiol 125:188-96.

Fredslund J, Schauser L, Madsen LH, Sandal N, Stougaard J, 2005. PriFi: using a multiple alignment of related sequences to find primers for amplification of homologs. Nucleic Acids Res 1:33.

Frohbieter KA, Ismail B, Nielsen SS, Hayes KD, 2005. Effects of Pseudomonas fluorescens M3/6 bacterial protease on plasmin system and plasminogen activation. J Dairy Sci 88:3392-401.

Ismail B, Nielsen SS, 2010. Invited review: plasmin protease in milk: current knowledge and relevance to dairy industry. J Dairy Sci 93:4999-5009.

Kessler E, Safrin M, 2014. Elastinolytic and proteolytic enzymes. Methods Mol Biol 1149:135-69.

Liu M, Wang H, Griffiths MW, 2007. Regulation of alkaline metalloprotease promoter by $\mathrm{N}$ acyl homoserine lactone quorum sensing in Pseudomonas fluorescens. J Appl Microbiol 103:2174-84.

Liao CH, McCallus DE, 1998. Biochemical and genetic characterization of an extracellular protease from Pseudomonas fluorescens CY091. Appl Environ Microbiol 64:914-21.

Marchand S, Coudijzer K, Heyndrickx M, Dewettinck K, De Block J, 2008. Development of a method to select the heat resistant proteolytic activity of bacterial origin in raw milk samples. Int Dairy J 18:514-9.

Marchand S, Heylen K, Messens W, Coudijzer K, De Vos P, Dewettinck K, Herman L, De Block J, Heyndrickx M, 2009a. Seasonal influence on heat-resistant proteolytic capacity of Pseudomonas lundensis and Pseudomonas fragi, predominant milk spoilers isolated from Belgian raw milk samples. Environ Microbiol 1:467-82.

Marchand S, Vandriesche G, Coorevits A, Coudijzer K, De Jonghe V, Dewettinck K, De Vos P, Devreese B, Heyndrickx M, De Block J, 2009b. Heterogeneity of heatresistant proteases from milk Pseudomonas species. Int J Food Microbiol 133:68-77.

Martino ME, Fasolato, L, Montemurro F, Rosteghin M, Manfrin A, Patarnello T, Novelli E, Cardazzo B, 2011. Determination of microbial diversity of Aeromonas strains on the basis of multilocus sequence typing, phenotype and presence of putative virulence genes. Appl Environ Microbiol 77:4986-5000.

Maunsell B, Adams C, 0'Gara F, 2006. Complex regulation of AprA metalloprotease in Pseudomonas fluorescens M114: evidence for the involvement of iron, the ECF sigma factor, PbrA and pseudobactin M114 siderophore. Microbiology 152:29-42

Morales P, Fernández-García E, Nuñez M, 2005. Volatile compounds produced in cheese by Pseudomonas strains of dairy origin belonging to six different species. J Agr Food Chem 53:6835-43.

Mulet M, Lalucat J, Garcìa-Valdes E, 2010. DNA sequence-based analysis of the Pseudomonas species. Environ Microbiol 12:1513-30.

Nicodeme M, Grill JP, Humbert G, Gaillard JL, 2005. Extracellular protease activity of different Pseudomonas strains: dependence of proteolytic activity on culture conditions. J Appl Microbiol 99:641-8.

Rauh VM, Johansen LB, Ipsen R, Paulsson M, Larsen LB, Hammersh M, 2014. Plasmin activity in UHT milk: relationship between proteolysis, age gelation, and bitterness. J Agr Food Chem 62:6852-60.

Woods RG, Burger M, Beven CA, Beacham IR, 2001. The aprX-lipA operon of Pseudomonas fluorescens B52: a molecular analysis of metalloprotease and lipase production. Microbiology 147:345-54. 